\title{
A DYNAMIC CONTEXT OF BEHAVIOURAL STRATEGY: MANAGERIAL COGNITIVE CAPABILITIES AND ORGANIZATIONAL ADAPTIVE PERFORMANCE
}

\section{DYNAMICZNY KONTEKST STRATEGII BEHAWIORALNEJ: MENEDŻERSKIE ZDOLNOŚCI POZNAWCZE I ORGANIZACYJNA ADAPTACYJNOŚĆ}

\author{
Katarzyna Piórkowska
}

Wrocław University of Economics, e-mail: katarzyna.piorkowska@ue.wroc.pl

\begin{abstract}
Summary: The prior research has emphasized the importance of either individuals to organizational performance or of managerial cognition to strategic change and action and provided support for the salient role of managerial cognition in developing managerial capabilities and behaviour. Nevertheless, given that managerial perceptions may vary across industry contexts and that high and low velocity industry pose different cognitive challenges to managers, there is no prior research investigating the associations between managerial cognitive and adaptive capabilities, the individual propensity to adapt, and organizational adaptive performance in a high velocity industry, only some research has explored how individual characteristics affect the ability to develop adaptive capabilities. Hence the aim of the paper is to present a theoretical and methodological proposition exploiting a cognitive approach and a microfoundations perspective in strategic management, aiming to examine the interdependencies between managerial cognitive capabilities ,adaptive capabilities, and organizational adaptive performance as well as explore the moderators and/or mediators of that relationship. The method used is the literature review. The main findings constitute the propositions resulting from a developed conceptual framework.
\end{abstract}

Keywords: behavioural strategy, micro-foundations, adaptive performance.
Streszczenie: Dotychczasowe badania podkreślają znaczenie wpływu jednostki na organizacyjną efektywność oraz wpływu menedżerskiego poznania na zmianę strategiczną, uwypuklając przy tym rolę menedżerskiego poznania w kształtowaniu menedżerskich zdolności i zachowań. Jednakże, biorąc pod uwagę zróżnicowanie menedżerskiej percepcji w zależności od kontekstu, obserwuje się wyraźną lukę badawczą w odniesieniu do zależności między menedżerskimi poznawczymi i adaptacyjnymi zdolnościami, indywidualnymi skłonnościami do adaptowania się a organizacyjną adaptacyjnością zwłaszcza w sektorach o dużej zmienności. Celem artykułu jest zaprezentowanie teoretycznych i metodycznych propozycji w podejściach poznawczym i mikrofundamentalnym w ogóle w zarządzaniu strategicznym. Celem szczegółowym jest analiza zależności między menedżerskimi poznawczymi i adaptacyjnymi zdolnościami a organizacyjną adaptacyjnością oraz zaproponowanie mediatorów i moderatorów tychże relacji. Cel osiągnięto z zastosowaniem przeglądu literatury. Efekty opisanych rozważań sprowadzają się do opracowania konceptu badawczego i sformułowania propozycji badawczych z niego wynikających.

Słowa kluczowe: strategia behawioralna, mikrofundamenty, organizacyjna adaptacyjność. 


\section{Introduction}

The paper is mainly embedded in the strategic management field in terms of the behavioural strategy concept, adaptability construct as well as the realm of micro-foundations.

The behavioural strategy concept pertains to explain how and through which mechanisms managerial behaviour affects organizational strategies. Behavioural strategy merges cognitive and social psychology with strategic management theory and practice and aims to bring realistic assumptions about human cognition, emotions and social behaviour to the strategic management [Powell et al. 2011, p. 1371]. Consequently, the phenomenon of 'behavioural strategy' might be involved in the microfoundations field in strategic management.

The dynamic context of behavioural strategy involves the issues of adapting to environmental uncertainty and changes. Organizations are embedded in a dynamic context where decision strategies and environments mutually influence each other (e.g. [Mingers, White 2010]). A distinctive characteristic of an entrepreneurial firm is its flexibility in adapting to a rapidly changing environment [Yiu et al. 2007]. The flexibility and adaptation (as well as adaptability) is strictly interrelated with adaptive capabilities constituting an instance of dynamic capabilities (compare [Cyfert, Krzakiewicz 2016, p. 279]). Wang and Ahmed [2007] identified three components of dynamic capabilities, namely absorptive, innovative and adaptive capabilities. Adaptive capabilities are necessary for identifying and assessing emerging market opportunities [Wang, Ahmed 2007]. Adaptive capability is strongly linked to the company's strategic action with respect to changing its abilities and organizational competences as well as coordinating, recombining, and allocating resources in order to meet the requirements of a changing environment [Kaehler et al. 2014, p. 2; Lu et al. 2010, p. 420].

It is proposed to examine the concept of adaptive capabilities at the individual level called 'managerial adaptive capabilities' since the micro-foundations of organizational capabilities encompass their constituent components, such as individuals and processes, and the interactions. In particular, the role of individuals is crucial to understanding capabilities and their development [Felin, Hesterly 2007].

Managerial adaptive capabilities are hypothesized to be determined by cognitive frames, especially managerial cognitive capabilities - the concept introduced by Helfat and Peteraf [2015] and individual propensity to adapt understood as adaptive change attitude (willingness to change - e.g. [Metselaar 1997]). Hodgkinson and Healey [2011] pointed out that explicit and implicit cognitive processes are essential constituents in the development of dynamic capabilities. Cognitive factors, beyond behavioural and environmental ones, constitute the residuum of causal ambiguity [Powell et al. 2006] and cognitive capabilities are one of the perspectives exploring cognition in management research.

An adaptability construct is context-specific and concerns both internal aspects (e.g. [O'Connell et al. 2008; Ployhard, Bliese 2006; Zhou, Li 2010]) and external environment characteristics, especially dynamic ones (e.g. [Brown, Eisenhardt 1997; Eisenhardt, Martin 2000]).

Specifically, this paper analyses how managerial cognitive capabilities influence managerial adaptive capabilities and those might affect organizational adaptive performance in terms of strategic response. Prior research has emphasized the importance of either individuals to organizational performance or of managerial cognition to strategic change and action (e.g. [Kaplan et al. 2003; Nadkarni, Barr 2008] and provides support for the salient role of managerial cognition in developing managerial capabilities and behaviour). Nevertheless, given that managerial perceptions may vary across industry contexts and that high and low velocity industries pose different cognitive challenges to managers (e.g. [Nadkarni, Baar 2008, pp. 1398-1399]), there is no prior research investigating the associations between managerial cognitive and adaptive capabilities, the individual propensity to adapt, and organizational adaptive performance in a high velocity industry, e.g. a commercial medical sector in which the research framework is proposed to be implemented, only some little research has explored how individual characteristics affect the ability to develop adaptive capabilities (e.g. [Adner, Helfat 2006]). Hence, the aim of the paper is to present a theoretical and methodological proposition exploiting a cognitive approach and micro-foundations perspective in strategic management, aiming to examine the interdependencies between managerial cognitive and adaptive capabilities and explore the moderators and/or mediators of that relationship.

The paper is three fold. The first section presents the rationale and conceptual framework concerning managerial cognitive and adaptive capabilities, individual propensity to adapt as well as organizational adaptive performance. The second section highlights the measurement tools proposed. Finally, the conclusions, especially in terms of future research directions have been posed.

The publication is realized in the scope of the project that has been financed by the National Scientific Centre in Poland on the basis of decision no. DEC-2012/05/D/ HS4/01317 ${ }^{1}$.

${ }^{1}$ An extended version of the paper was presented at the 30th Annual British Academy of Management Conference 2016, "Thriving in Turbulent Times", British Academy of Management, Newcastle University, 06-08.09.2016 Newcastle. 


\section{Managerial cognitive and adaptive capabilities, individual propensity to adapt and organizational adaptive performance - rationale and a conceptual framework}

In a dynamic environment, performance differences might be influenced by capabilities understood as organisational processes that allow resources to be deployed [Helfat, Winter 2011] in responding quickly to change (e.g. [Eisenhardt, Martin 2000; Helfat et al. 2007; Zollo, Winter 2002]). Makadok [2001, p. 389] defines a capability as 'a special type of resource - specifically an organizationally embedded non-transferable, firm-specific resource whose purpose is to improve the productivity of the other resources possessed by the firm'. Amit and Schoemaker [1993, p. 35] argue that firm-specific capabilities can be regarded as 'intermediate goods' generated by the firm to provide enhanced productivity of its resources.

An adaptive capability, as one type of dynamic capabilities, reveals in putting new ideas into action, modifying existing product attributes to meet changes in customer demand, amending existing products to explore new markets, and/or upgrading products rapidly [Lu et al. 2010, p. 423].

The capability to transform internal organizational resources in response to environmental changes is consistently linked to competitive advantage and fundamental to management research [Hoopes, Madsen 2008; Teece et al. 1997]. Hence a managerial adaptive capability - a disaggregated higher-level strategic capability (a micro-foundation) (e.g. [Abell et al. 2008]), as a core dynamic managerial capability, reflects managers' capacity to reconfigure resources and adapt processes in an efficient and effective response to a changing environment [Gibson, Birkinshaw 2004]. It comprises the managerial capacity to search for new opportunities, proceed with relevant external and internal information and manage recursive relationships between adaptive capacity and structuration processes [Oktemgil, Greenley 1997; Staber, Sydow 2002]. Key elements of adaptive capabilities are the abilities to respond to external product market opportunities, investment in marketing activities, and the speed of response to changing market conditions [Biedenbach, Müller 2010, cf. Chakravarthy 1982] as well as the ability to identify and capitalize on emerging market opportunities (e.g. [Chakravarthy 1982; Wang, Ahmed 2007]). Thus, managerial strategic decision-making processes connected mainly with adapting to a changing environment through reconfiguring and reallocating organizational resources, and have been labelled managerial adaptive capability [Adner, Helfat 2003; Kor, Mesko 2013; Ma et al. 2009]. Building an adaptive capability requires internal efforts and draws on internal firm-specific resources.

The behavioural and cognitive mechanisms by which managers adapt to a changing environment have been of central importance to strategy and strategic management scholars, at least since the 1960s - Carnegie School's contributions to the behavioural theory of the firm (e.g. [Cyert, March 1963; Simon 1947]) and the psychological contribution from behavioural decision research (e.g. [Tversky, Kahneman 1974]) where managerial cognition is regarded as a source of heterogeneity in firm strategies and performance [Gary, Wood 2011; Hough, Ogilvie 2005]. According to Gavetti and Ocasio [2015], the last decade has witnessed a dramatic rise in empirical studies that seek to document the role of cognition in strategic outcomes, and in theoretical work that seeks to systematize this relationship. Cognitive capabilities are one of the perspectives exploring cognition in management research (e.g. [Helfat, Peteraf 2015]). They have been evidenced as a strong predictor of adaptability and adaptive performance (e.g. [Allworth, Hesketh 1999; Bell, Kozlowski 2008; Helfat, Peteraf 2015; LePine 2005; LePine et al. 2000]). Helfat and Peteraf [2015, p. 835] consider cognitive capabilities as the cognitive capacity (potential ability) of an individual manager to perform one or more of the mental activities that comprise cognition. Individuals differ in capabilities of accurately allocating attentional resources to respond to contingencies in the environment. The most compelling managerial cognitive capabilities and cognitive predictors of individual propensity to adapt to environmental changes are likely to draw on attention, individual mindfulness, consciousness, and cognitive flexibility (including working memory capacity) - they all pertain to transfer the knowledge in a new and altering context. Attention constitutes a primary filter for identifying issues [Nadkarni, Baar 2008] as well as a state of focused awareness on a subset of available perceptual information [American Psychological Association 2009]. Posner and Petersen [1990] suggest three major functions of attention: (a) orienting to sensory events, (b) detecting signals for focal processes, and (c) maintaining a vigilant or alert state. Cognitive capabilities of attention may affect the way in which managers more accurately sense new opportunities and threats [Helfat, Peteraf 2015, p. 839]. Individual mindfulness is a multi-faceted phenomenon. The definitions vary depending on the Western or Eastern approach. In attempting to reconcile the Western and Eastern proposals of explaining the individual mindfulness phenomenon, it has been assumed that it constitutes an intended process in between the state and the trait resulting in capabilities of keeping affectionate attention, past, moment-to-moment (active) and judgmental awareness as well as of controlling the attention quality. In practice, it is reflected in Langer's mindfulness components: openness to novelty, alertness to distinction, sensitivity to different context, awareness of multiple perspectives, and orientation in the past and present (the last component has been modified) (see [Langer $1989 ;$ 1997]). Consciousness also concerns processing 
attentional resources. Individuals revealing high levels of consciousness are likely to be detail oriented and successful in problem solving [Barrick et al. 1993; Griffin, Hesketh 2005; Shoss et al. 2012, p. 913]. It ought to be stated that both consciousness and attention occur in levels and grades, they are not monoliths, and they influence each other in a sort of upward spiral [Damasio 2000, p. 91]. Consciousness encompasses both awareness and attention [Brown, Ryan 2003]. These aforementioned cognitive predictors relate to cognitive flexibility - the capacity to flexibly interpret the context and respond to it (e.g. [Herr 1993; Martin, Rubin 1995]).

Managerial adapting to environmental uncertainty and changes involves an individual propensity to adapt (as willingness to change - [Metselaar 1997]) as well. It is a relatively stable individual difference influencing how individuals interpret and respond to a situation. Adaptable individuals tend to be more sensitive to environmental cues and less vulnerable to resource loss and more capable of gaining resources [Van den Heuvel et al. 2013, p. 13; Van den Heuvel et al. 2009]. Ployhard and Bliese [2006] proposed an I-ADAPT model involving individual differences (trait-like individual differences) in adaptability and they differentiated the following eight dimensions of individual adaptability: crisis, work stress, creativity, uncertainty, learning, interpersonal, cultural, and physical.

Adaptive capabilities are influenced by the firm's environmental velocity and dynamism [Baum, Wally 2003; Teece et al. 1997] - both velocity and dynamism are important concepts in strategic decision research. Hence it has been hypothesized that environmental uncertainty and environmental dynamism might affect the organizational adaptive performance understood as organisational strategic response [e.g. Nadkarni, Barr 2008]. Baum and Wally [2003, p. 1110] hypothesized that the faster the strategic decision-making, the better the firm performance in terms of growth and profitability. Research suggests that adaptability should lead to an improved performance [Bourgeois 1980; Snow, Hrebiniak 1980]. As well as this, it might influence the relationship between individual propensity to adapt and managerial adaptive capabilities. Furthermore, it seems that strategic orientation dimensions (customer, competitor, and technology), reflecting an outward looking view of the fit between strategic choices and environment [Voss, Voss 2000; Zhou, Li 2010], has an impact on managerial adaptive capabilities (inward looking) and organizational adaptive performance in the end. For instance, Grinstein [2008] identified market orientation as a key factor of adaptability in highly competitive environments.

The logic of the aforementioned considerations is presented in Figure 1.

Consequently, the following propositions have been formulated:

Proposition 1: Managerial cognitive capabilities influence the intensity of the individual propensity to adapt.

Proposition 2: The individual propensity to adapt mediates the relationship between managerial cognitive capabilities and managerial adaptive capabilities.

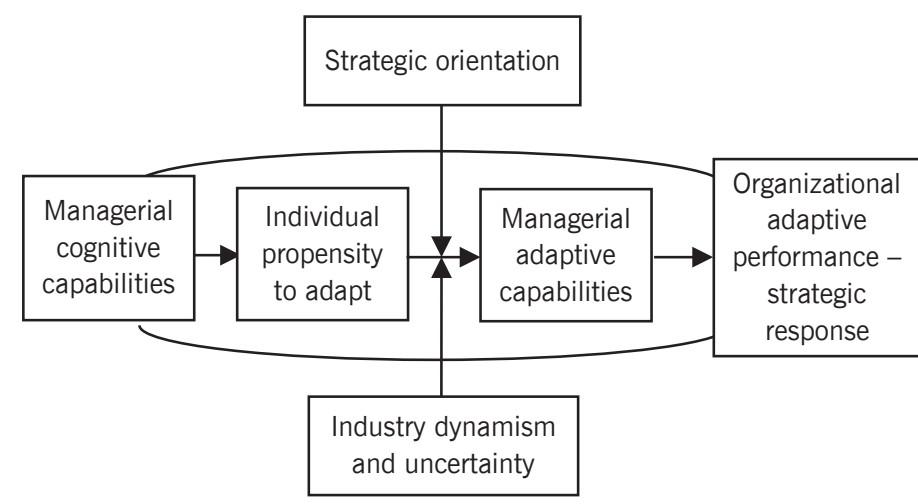

Fig. 1. A conceptual framework

Source: own study.

Proposition 3: Strategic orientation moderates the relationship between the individual propensity to adapt and managerial adaptive capabilities.

Proposition 4: Industry dynamism (change rate) and industry uncertainty moderates the relationship between the individual propensity to adapt and managerial adaptive capabilities.

Proposition 5: Managerial adaptive capabilities might influence organizational adaptive performance in terms of strategic response.

\section{Research framework: measurement tools}

It is proposed to implement the given framework in a commercial medical sector that represents a very dynamic and uncertain industry in which managerial abilities to adapt are extremely important.

The following measures are going to be used in the study proposed:

1. Managerial cognitive capabilities:

- Attention

It is suggested that using The Test of Everyday Attention for a comprehensive assessment of attention performance - developed by Robertson et al. [1996], yet it is based on Posner and Petersen's [1990] measure of attention. It captures different aspects of attention, e.g. sustained attention, divided attention and attentional switching. The test-retest reliability of the test items has been reported to be sufficient (correlation coefficient ranges from 0.61 to 0.9 ).

- Individual mindfulness

It is considered to adopt either the dispositional Brown and Ryan's [2003] Mindful Attention Awareness Scale (MAAS) - in all subsequent samples, the MAAS factorial structure and reliability were confirmed, or the Five-Facet Mindfulness Questionnaire (FFMQ) [Baer et al. 2006] - the five facets include: acting with awareness, non-judging of inner experience, non-reactivity to inner experience, describing, and observing. This model fits the data well (CFI $=.97, \mathrm{TLI}=$ .95 , RMSEA $=.07$ [90\% confidence interval: .05 to 
$.08]$, SRMR $=.05)$, or Bodner and Langer's [2001] Mindfulness/Mindlessness Scale (MMS) - the items assess four components: Flexibility, Novelty Seeking, Novelty Producing, and Engagement.

- Self-Consciousness

It is proposed to use the Self-Consciousness Scale (SCS) [Fenigstein et al. 1975]. It has three subscales. Private Self-Consciousness, Public Self-Consciousness, and Social Anxiety.

- Cognitive/behavioural flexibility

Cognitive/behavioural flexibility is going to be assessed using the seven-item Environmental Mastery subscale of the Scales of Psychological Well-Being questionnaire (SPWB) [Ryff 1989].

2. Individual propensity to adapt

It is planned to adopt Ployhard and Bliese's [2006] I-ADAPT model.

3. Managerial adaptive capability

It is proposed to adopt, to reconstruct for an individual level, and to validate Ma, Yao and Xi's [2009] firm's strategic adaptive capability scale measuring: (1) handling potential threats from important stake-holders; (2) removing unexpected obstacles that emerged in the competitive environment; (3) adapting quickly to sudden changes in industrial policies, and (4) succeeding in an intensely competitive business environment.

4. Organizational adaptive performance

It is planned to assess strategic response timeliness by means of decision scenarios (see [Baum, Wally 2003]).

5. Strategic orientation

It is going to incorporate the scale for measuring three dimensions: customer, competitor, and technology used in Zhou and Li's [2010] study, adopted from Gatington and Xuereb [1997].

6. Environmental uncertainty

It is going to use the questionnaire measuring perceived environmental uncertainty, using five bipolar items from a scale adapted from an instrument developed by Khandwalla [1976]. The environmental uncertainty measure has an alpha coefficient of 0.65 .

7. Environmental dynamism

It is measured by using items assessing: the market activities of competitors (in terms of predictability, hostility, degree of affecting), the tastes and preferences of customers in a principal industry, the rate of innovation of new operating processes and new products or services in a principal industry, the principal industry's downswings and upswings, and the needed diversity in production methods and marketing tactics to cater to different customers [Miller, Friesen 1982]. The overall Cronbach's alfa was 0.81 . Control variables: Industry type - a dummy variable; Firm size - as a study would concern micro- and small companies; technological change within an organization [Khandwalla 1976]; competitive intensity [Jaworski, Kohli 1993].

\section{Conclusion}

This study addresses a research gap pertaining to how managerial cognitive capabilities, the managerial propensity to adapt, and managerial adaptive capabilities, potentially contribute to the development of organizational adaptive performance in terms of strategic response.

According to future research directions, first, it is suggested empirically examining aforementioned relationships. Secondly, it is worth scrutinizing the mutual relationships between selected cognitive capabilities. For instance, the notion 'mindful attention' [Weick 1995; Nadkarni and Barr 2008] emphasizing the associations between attention and mindfulness ought to be distinguished. Finally, it is recommend to take into account the learning processes' impact on the relationships between managerial cognitive and adaptive capabilities in the qualitative manner.

\section{Literature}

Abell P., Felin T., Foss N., 2008, Building micro-foundations for the routines, capabilities, and performance links, Managerial and Decision Economics, vol. 29, pp. 489-502.

Adner R., Helfat C.E., 2003, Corporate effects and dynamic managerial capabilities, Strategic Management Journal, vol. 24 (10), pp. 1011-1025, Special Issue: Why Is There a Resource-Based View? Toward a Theory of Competitive Heterogeneity (Oct. 2003).

American Psychological Association, 2009, Glossary of Psychological Terms.

Amit R., Schoemaker P., 1993, Strategic assets and organizational rent, Strategic Management Journal, vol. 14 (1), pp. 33-46.

Baer R.A., Smith G.T., Hopkins J., Krietemeyer J., Toney L., 2006, Using self-report assessment methods to explore facets of mindfulness, Assessment, vol. 13, pp. 27-45.

Barrick M., Mount M., Strauss J., 1993, Conscientiousness and performance of sales representatives: Test of the mediating effects of goal setting, Journal of Applied Psychology, vol. 78, pp. 715-722.

Baum J.R., Wally S., 2003, Strategic decision speed and firm performance, Strategic Management Journal, vol. 24, pp. 1107-1129 .

Biedenbach T., Müller R., 2012, Absorptive, innovative and adaptive capabilities and their impact on project and project portfolio performance, International Journal of Project Management, vol. 30, pp. 621-635.

Bodner T.E., Langer E.J., 2001, Individual differences in mindfulness: The mindfulness/mindlessness scale, poster presentation at the 13th annual American Psychological Society Convention, Toronto, Ontario, Canada.

Bourgeois L.J III., 1980, Strategy and environment: A conceptual integration, The Academy of Management Review, vol. 5 (1), pp. 25-39.

Brown S.L, Eisenhardt K.M., 1997, The art of continuous change: Linking complexity theory and time-paced evolution in relentlessly shifting organizations, Administrative Science Quarterly, vol. 42 (1), pp. 1-34.

Brown K.W., Ryan R.M., 2003, The benefits of being present: Mindfulness and its role in psychological well-being, Journal of Personality and Social Psychology, vol. 84, pp. 822-848. 
Chakravarthy B.S., 1982, Adaptation: A promising metaphor for strategic management, Academy of Management Review, vol. 7 (1), pp. 35-44.

Cyfert Sz., Krzakiewicz K., 2016, The role of opportunity sensing and learning processes in shaping dynamic capabilities in Polish enterprises, Management, vol. 20, no. 1, pp. 271$-299$.

Damasio A., 2000, The Feeling of What Happens, Heinemann, London.

Eisenhardt K.M., Martin J.A., 2000, Dynamic capabilities: What are they?, Strategic Management Journal, vol. 21, pp. 1105$-1121$.

Felin T., Hesterly W.S., 2007, The knowledge-based view, nested heterogeneity, and new value creation: philosophical considerations on the locus of knowledge, Academy of Management Review, vol. 32 (1), pp. 195-218.

Fenigstein A., Scheier M.F., Buss A.H., 1975, Public and private self-consciousness: Assessment and theory, Journal of Consulting and Clinical Psychology, vol. 43, pp. 522-527.

Gatignon H, Xuereb J.M., 1997, Strategic orientation of the firm and new product performance, Journal of Marketing Research, vol. 34 (1), pp. 77-90.

Gavetti G., 2005, Cognition and hierarchy: Rethinking the microfoundations of capabilities' development, Organization Science, vol. 16 (6), pp. 599-617.

Gavetti G., Levinthal D., 2000, Looking forward and looking backward: Cognitive and experiential search, Administrative Science Quarterly, vol. 45(1), pp. 113-137.

Gavetti G., Ocasio W., 2015, Cognition and Strategy. Advances in Strategy Management, Emerald Group Publishing Limited, Bingley.

Gibson G.B., Birkinshaw J., 2004, The antecedents, consequences, and mediating role of organizational ambidexterity, Academy Management Journal, vol. 47 (2), pp. 209-26.

Griffin B., Hesketh B., 2005, Are conscientious workers adaptable?, Australian Journal of Management, vol. 30 (2), pp. 245$-259$.

Grinstein A., 2008, The relationships between market orientation and alternative strategic orientations A meta-analysis, European Journal of Marketing, vol. 42 (1/2), pp. 115-134.

Helfat C., Finkelstein S., Mitchell W., Peteraf M., Singh H., Teece D., Winter S., 2007, Dynamic Capabilities: Understanding Strategic Change in Organisations, Blackwell Publishing, Malden.

Helfat C.E., Peteraf M.A., 2015, Managerial cognitive capabilities and the microfoundations of dynamic capabilities, Strategic Management Journal, vol. 36, pp. 831-850.

Helfat C.E., Winter S.G., 2011, Untangling dynamic and operational capabilities: strategy for the (n)ever-changing world, Strategic Management Journal, vol. 32, pp. 1243-1250.

Herr E.L., 1993, Contexts and influences on the need for personal flexibility for the 21st Century, Canadian Journal of Counseling, vol. 27, pp. 48-164.

Hodgkinson G.P., Healey M.P., 2011, Psychological foundations of dynamic capabilities: Reflexion and reflection in strategic management, Strategic Management Journal, vol. 32, pp. $1500-1516$

Hoopes D.G., Madsen, T.L., 2008, A capability-based view of competitive heterogeneity, Industrial and Corporate Change, vol. 17 (3), pp. 393-426.

Kaehler C., Busatto F., Becker G.V., Hansen P.B., Santos J.L.S., 2014, Relationship between adaptive capability and strategic orientation: An empirical study in a Brazilian company, iBusiness, vol. 6, pp. 1-9, puhttp://www.scirp.org/journal/ib. http://dx.doi.org/10.4236/ib.2014.61001.
Kaplan S., Murray F., Henderson R., 2003, Discontinuities and senior management: assessing the role of recognition in pharmaceutical firm response to biotechnology, Industrial and Corporate Change, vol. 12 (2), pp. 203-233.

Khandwalla P.N., 1976, The Design of Organizations, Harcourt Brace Jovanovich, New York.

Kor Y.Y., Mesko A., 2013, Dynamic managerial capabilities: Configuration and orchestration of top executives' capabilities and the firm's dominant logic, Strategic Management Journal, vol. 34, pp. 233-244.

Langer E.J., 1989, Mindfulness, Addison-Wesley, Reading, MA.

Langer E.J., 1997, The power of mindful learning, Addison-Wesley, Reading, MA.

Lu Y., Zhou L., Bruton G., Li W., 2010, Capabilities as a mediator linking resources and the international performance of entrepreneurial firms in an emerging economy, Journal of International Business Studies, vol. 41, pp. 419-436.

Ma X., Yao X., Xi Y., 2009, How do interorganizational and interpersonal networks affect a firm's strategic adaptive capability in a transition economy?, Journal of Business Research, vol. 62 (11), pp. 1087-1095.

Makadok R., 2001, Toward a synthesis of the resource-based and dynamic-capability views of rent creation, Strategic Management Journal, vol. 22 (5), pp. 387-401.

Martin M.M., Rubin R.B., 1995, A new measure of cognitive flexibility, Psychological Reports, vol. 76, pp. 623-626.

Metselaar E.E., 1997, Assessing the Adaptive Attitudes; Construction and Validation of the DINAMO, VU, Amsterdam.

Miller D. Friesen P.H., 1983, Strategy-making and environment: The third link, Strategic Management Journal, vol. 4 (3), pp. 221-235.

Mingers J., White L., 2010, A review of the recent contribution of systems thinking to operational research and management science, European Journal of Operational Research, vol. 207 (3), pp. 1147-1161.

Nadkarni S., Barr P.S., 2008, Environmental context, managerial cognition, and strategic action: An integrated view, Strategic Management Journal, vol. 29 (13), pp. 1395-1427.

O'Connell D.J., McNeely E., Hall D.T., 2008, Unpacking personal adaptability at work, Journal of Leadership, Organizational Studies, vol. 14, pp. 248-259.

Oktemgil M., Greenley G., 1997, Consequences of high and low adaptive capability in UK companies, European Journal of Marketing, vol. 31 (7), pp. 445-506.

Ployhart R.E., Bliese P.D., 2006, Individual ADAPTability (IADAPT) theory: Conceptualizing the Antecedents, Consequences, and Measurement of Individual Differences in Adaptability, [in:] Burke S., Pierce L., Salas E. (eds.), Understanding Adaptability: A Prerequisite For Effective Performance Within Complex Environments, Elsevier Science, St. Louis, MO, pp. 3-39.

Posner M.I., Petersen S.E., 1990, The attention system of the human brain, Annual Review of Neuroscience, vol. 13, pp. 25-42.

Posner M.I., Rothbart M., 2007, Research on attention networks as a model for the integration of psychological science, Annual Review of Psychology, vol. 58, pp. 1-23.

Powell T.C., Lovallo D., Fox C.R., 2011, Behavioral strategy, Strategic Management Journal, vol. 32, pp. 1369-1386.

Robertson I.H., Ward T., Ridgeway V., Nimmo-Smith I., 1996, The structure of normal human attention: The test of everyday attention, Journal of the International Neuropsychological Society, vol. 2, pp. 525-534.

Ryff C.D., 1989, Happiness is everything, or is it? Explorations on the meaning of psychological well-being, Journal of Personality and Social Psychology, vol. 57, pp. 1069-1081. 
Schilke 0., 2014, On the contingent value of dynamic capabilities for competitive advantage: The nonlinear moderating effect of environmental dynamism, Strategic Management Journal, vol. 35 (2), pp. 179-203.

Shoss M.K., Witt L.A., Vera D., 2012, When does adaptive performance lead to higher task performance?, Journal of Organizational Behavior, vol. 33, pp. 910-924.

Snow C.C., Hrebiniak L.G., 1980, Strategy, distinctive competence, and organizational performance, Administrative Science Quarterly, vol. 25 (2), pp. 317-336.

Staber U., Sydow J., 2002, Organizational adaptive capacity a structuration perspective, Journal of Management Inquiry, vol. 11 (4), pp. 408-424.

Sutcliffe K.M., Zaheer A., 1998, Uncertainty in the transaction environment: An empirical test, Strategic Management Journal, vol. 19, pp. 1-23.

Teece D.J., Pisano G., Shuen A., 1997, Dynamic capabilities and strategic management, Strategic Management Journal, vol. 18 (7), pp. 509-533.

Tripsas M., Gavetti G., 2000, Capabilities, cognition, and inertia: Evidence from digital imaging, Strategic Management Journal, vol. 21 (10/11), pp. 1147-1161, Special Issue: The EvoIution of Firm Capabilities (Oct.-Nov. 2000).

Van den Heuvel M., Demerouti E., Schreurs B.H.J., Bakker A.B., Schaufeli W.B., 2009, Does meaning-making help during or- ganizational change? Development and validation of a new scale, Career Development International, vol. 14, pp. 508-533.

Van den Heuvel M., Demerouti E., Bakker A.B., Schaufeli W.B., 2013, Adapting to change: The value of change information and meaning-making, Journal of Vocational Behavior, vol. 83, pp. 11-21.

Voss G., Voss Z., 2000, Strategic orientation and firm performance in an artistic environment, Journal of Marketing, vol. 64 (1), pp. 67-83.

Wang C.L., Ahmed P.K., 2007, Dynamic capabilities: A review and research agenda, International Journal of Management Review, vol. 9 (1), pp. 31-51.

Yiu D.W., Lau C.M., Bruton G.D., 2007, International venturing by emerging economy firms: The effects of firm capabilities, home country networks, and corporate entrepreneurship, Journal of International Business Studies, vol. 38 (4), pp. 519-540.

Zhou K.Z., Li C.B., 2010, How strategic orientations influence the building of dynamic capability in emerging economies, Journal of Business Research, vol. 63, pp. 224-231.

Zollo M., Winter S., 2002, Deliberate learning and the evolution of dynamic capabilities, Organization Science, vol. 13 (3), pp. 339-353. 